\title{
Pharmacognostic Characterization, Bioactive Compounds and Powder Antioxidant Action of Leaves of Araca (Psidium cattleianum(Myrtaceae))
}

\author{
Faleiro $\mathrm{JH}^{1}$, Gonçalves $\mathrm{RC}^{2}$, Faleiro Naves $\mathrm{PL}^{3}$, Guimarães dos Santos $\mathrm{MN}^{4}$, Costa Celestino $\mathrm{SM}^{5}$ and Malafaia $\mathrm{G}^{6^{*}}$ \\ ${ }^{1}$ Graduate Program in Chemistry, Federal University of Goiás - Campus Catalão, GO, Brazil \\ ${ }^{2}$ Graduate Program in Tropical Medicine and Public Health, Federal University of Goias - Goiania, GO, Brazil \\ ${ }^{3}$ Graduate Program in Molecular Sciences, State University of Goias - Campus Anapolis, GO, Brazil \\ ${ }^{4}$ Program Graduate in Food Science and Technology, Federal University of Goias - Goiania, GO, Brazil \\ ${ }^{5}$ Embrapa Cerrados - Planaltina, DF, Brazil
}

${ }^{6}$ Departament of Biological Sciences, Laboratory of Biological Research of the Federal Institute Goiano -Campus Urutaí, GO, Brazil

"Corresponding author: Guilherme Malafaia, Department of Biological Sciences, Federal Institute Goiano Campus Urutaí, Highway Geraldo Silva Nascimento, Rural, Urutaí, GO, CEP 75790-000, Brazil, Tel: +55 643465 1995; Fax: +55 643465 1995; E-mail: guilhermeifgoiano@gmail.com

Rec date: July 18, 2016; Acc date: October 14, 2016; Pub date: October 19, 2016

Copyright: (๑) 2016 Faleiro JH, et al. This is an open-access article distributed under the terms of the Creative Commons Attribution License, which permits unrestricted use, distribution, and reproduction in any medium, provided the original author and source are credited.

\begin{abstract}
Araçás spp., have been used in traditional medicine for possessing several pharmacological properties such as antiseptic, digestive, anti-hemorrhagic, controlling blood pressure and diuretic. This study aimed to make a pharmacognostic characterization to establish control parameters of the plant drug quality (leaf), the determination of phenolic compounds, flavonoids, tannins, vitamin $C$ and $\beta$-carotene, and to evaluate the powder antioxidant capacity of Psidium cattleianum leaf. From powder of $P$. cattleianum leaves, pharmacognostic analyzes were performed and quantification assays of bioactive compounds and antioxidant activity by DPPH capture using spectrophotometric methods. In the pharmacognostic characterization were determined the density $\left(0.366 \mathrm{~g} . \mathrm{mL}^{-1} \pm 0.015\right)$, the ash content $(17.52 \% \pm 1.002)$, moisture $(9.32 \% \pm 1,006)$ and the $\mathrm{pH}(5.4 \pm 0.047)$. The quantification assays of phenolic compounds, flavonoids, tannins, vitamin $\mathrm{C}$, carotenoids and showed that the plant drug presents significant amounts of these bioactive compounds. The antioxidant activity analysis indicates that the leaf of this plant species has potentially active compounds in combating free radicals. The findings open perspectives for the realization of other biological assays for evidence of possible biological activities presented by the plant species in question.
\end{abstract}

Keywords: Traditional medicine; Secondary metabolites; Drugs; Free radicals

\section{Introduction}

Since the dawn of civilization, the use of substances of vegetable origin, in the form of extracts, powders and essential oils, have played an important role in the treatment, cure and prevention of various diseases that afflict humanity [1]. The medicinal effects of plants are related to a group of different metabolites, which are termed secondary metabolites, such as flavonoids, alkaloids, triterpenes, sesquiterpenes, tannins, lignins and others.

The secondary metabolites are defined as bioactive compounds that whose function is to adapt the plant to the environment, performing important functions such as defense against infection, injury, pests, pathogens, ultraviolet rays and herbivores [2-4]. These classes of substances, frequently, are targets of interest of researchers who see them as a promising source for discovery of new drugs, cosmetics and agrochemicals [5-7].

Botanical species of the family Myrtaceae (such as Pimenta dioica, Pimenta racemosa, Eucalyptus globulus, Syzygium aromaticum, Psidium guajava, Eugenia uniflora e Melaleuca alternifolia). They have been studied in scientific research over the years because they are promising candidates for the discovery of novel compounds having therapeutic properties [7-9]. It is also worth mentioning that the great diversity of species of this family, by being used in popular means and be the subject of scientific research, is described in Monographs of Pharmacopoéia Brasileira to ensure the safe medical use of these plants.

Among the Myrtaceae family, has the Araçazeiro (Psidium cattleianum), small shrub, distributed in a large area of Brazil, from Bahia to Rio Grande do Sul. This plant species has a very similar fruit to guava, but a little acider, is widely consumed in natura, in juices, jams and ice cream and has good acceptance by consumers. This plant is widely grown in home gardens, especially in the southern region [10-15].

In traditional medicine, the species has been used for various purposes, such as antiseptic, digestive, anti-hemorrhagic, controlling blood pressure and diuretic. There are reports, for example the use of leaves of this species in decoctions for treating diarrhoea. Referenced in the literature studies reinforce the pharmacological properties of fruits and leaves of Araçás spp., such as, for example, antioxidant activity, antimicrobial [4] and increased sleep induced by ketamine in mice.

Among the bioactive plant compounds that represent a significant pharmacological potential, especially the antioxidant activity in combating free radicals, highlights the phenolics, flavonoids, tannins, vitamin $C$ and $\beta$-carotene. It is known that the excess of free radicals in the human body may cause rupture of the cell and cellular content damage (proteins, lipids, carbohydrates and DNA) causing oxidative processes to tissues. Various pathological states such as acceleration of 
aging, cancer, cardiovascular disease, cataracts, decline of the immune system, and brain dysfunctions such as Alzheimer's are associated with uncontrolled production of free radicals in biological systems. Antioxidants are substances that react and neutralize the free radicals before they attack cells.

Although $P$. cattleianum spp., is been used in traditional culture, there is still no description of quality control parameters of the plant drug in the Brazilian Pharmacopoeia and studies on the bioactive compounds quantification and antioxidant activity of the leaves of this spp.,. Thus, this study was aimed to characterize pharmacognostic to establish quality control parameters of the plant drug (leaf), the determination of phenolic compounds, flavonoids, tannins, vitamin $\mathrm{C}$ and $\beta$-carotene, as well as evaluates the antioxidant capacity of $P$. cattleianum leaf powder [16-19].

\section{Material and Methods}

The $P$. cattleianum leaves were collected in the municipal district of Pire do Rio, State of Goiás, Brazil, in March 2014. A voucher specimen, under record number 9203 was deposited in herbarium of the State University of Goiás, University Unit of Exact Sciences and Technology (UEG/ UnUCET).

From the powdered dried leaves were determined in triplicate, the density of the plant drug powder, $\mathrm{pH}$, total ash content and moisture content. The tests to determining those parameters were conducted at Laboratory of Physical-Chemical analysis of the Federal Institute Goiano - Câmpus Urutaí, as described by the Pharmacopoeia Brazil [20].

Dosages assays were performed to phenolic compounds using Folin Ciocalteau method [21], flavonoids [22], tannins through the vanillin method [23] with three replicates for each sample. The absorbance readings were performed in the dark at room temperature in a spectrophotometer Thermo Fisher Scientific, Bio Mate Model 3. The results are expressed in milligrams per $100 \mathrm{~g}$ of sample. These tests were conducted at the Science and Food Technology Laboratory of Embrapa Cerrado (Planaltina - DF).

For evaluation of total carotenoid about $15 \mathrm{~g}$ of leaf powder were homogenized proceeding to extraction with pure acetone until no more observe of the characteristic color of the carotenoids in the residue. The extract was filtered through sintered funnel plate and transferred to a separatory funnel containing diethyl ether and petroleum ether (1:1). The extract was filtered with sodium sulfate to remove water. The extract was transferred to a $50 \mathrm{~mL}$ volumetric flask and measured with petroleum ether. Then there was the reading in spectrophotometer at $450 \mathrm{~nm}$, resetting the equipment with petroleum ether [24]

Quantification was performed by Equation:

$$
\mathrm{TC}(\mathrm{mg} / 100 \mathrm{~g})=\frac{10^{3} \times \mathrm{Abs} \times \mathrm{Vol}}{1 \% \mathrm{E} 1 \mathrm{~cm} \times \mathrm{m}}
$$

Where,

TC=Total carotenoid

Abs $=$ Absorbance at $450 \mathrm{~nm}$

Vol=balloon volume utilized in the dilution $(\mathrm{mL})$

$\mathrm{m}=$ sample weight $(\mathrm{g})$

$\mathrm{E} 1 \mathrm{~cm} 1 \%=2592$ (for $\beta$-Carotene in petroleum ether)
For evaluation of the vitamin $\mathrm{C}$, about $2 \mathrm{~g}$ of the leaf powder was weighed and mixed with $20 \mathrm{~mL}$ of an acid solution of $6 \% \mathrm{HPO}_{3}$, containing $2 \mathrm{~N}$ acetic acid. It was centrifuged at 15,000 rpm for $20 \mathrm{~min}$ at $4^{\circ} \mathrm{C}$, and filtered the supernatant. $1 \mathrm{~mL}$ of the solution was pipetted and added to $50 \mu \mathrm{L}$ solution of $0.2 \% 2.6$ dichlorophenolindophenol (DCPIP); it was stirred and incubated at room temperature for 1 hour. Add $1 \mathrm{~mL}$ of $2 \%$ thiourea and stir it well and then add $0.5 \mathrm{ml}$ of $2 \%$ dinitrophenylhydrazine (DNPH) solution (except white). Mixed, capped and leave in water bath at $60^{\circ} \mathrm{C}$ for $3 \mathrm{~h}$ (except white). Placed in an ice bath and added carefully $2.5 \mathrm{~mL}$ of cold $\mathrm{H}_{2} \mathrm{SO}_{4}$ (including white) and stirred and then $0.5 \mathrm{~mL}$ of $2 \% \mathrm{DNPH}$ white was added and stirred. Read the absorbance at $540 \mathrm{~nm}$. A standard solution of ascorbic acid (AA) with ascorbic acid in $100 \mathrm{ml}$ of acid solution 6\% $\mathrm{HPO}_{3}$, containing $2 \mathrm{~N}$ acetic acid was prepared for the calibration curve [25].

The antioxidant activity was determined according to the capture of free radical 2,2-diphenyl-1-picryl-hidrazila (DPPH) method, as described by Sánchez-Moreno et al. [26] with modifications. Briefly, in a $100 \mathrm{~mL}$ volumetric flask were added $1 \mathrm{~g}$ of leaf powder, $40 \mathrm{~mL}$ of $50 \%$ methanol and $40 \mathrm{~mL}$ of $70 \%$ acetone and completed the volume with distilled water. The reading was performed using aliquots of $100 \mu \mathrm{L}$ extract, at four different concentrations and added to $3.9 \mathrm{~mL}$ of methanol solution of DPPH (2,2-diphenyl-1-picryl-hidrazila) $6 \mu \mathrm{M}$. The absorbance readings were performed after incubation for $30 \mathrm{~min}$ in the dark, in environment temperature in spectrophotometer (Thermo Fisher Scientific, Bio Mate Model 3) at $515 \mathrm{~nm}$. The methyl alcohol was used as white, to calibrate the spectrophotometer.

To calculate the DPPH sequestration percentage was used the following equation: Radical DPPH sequestration $(\%)=[($ White absorbance-absorbance sample)/(absorbance white) $] \times 100$.

\section{Results and Discussion}

\section{Pharmacognostic characterization}

The results of the pharmacognostic analysis in $P$. cattleianum leaves are shown in Table 1.

\begin{tabular}{|l|l|}
\hline Parameters & Average results \pm Standard deviation \\
\hline Density & $0.366 \pm 0.015 \mathrm{~g} \cdot \mathrm{mL}^{-1}$ \\
\hline pH & $5.4 \pm 0.047$ \\
\hline Content of total ash & $16.98 \pm 1.002 \%$ \\
\hline Moisture content & $9.32 \pm 1.006 \%$ \\
\hline
\end{tabular}

Table 1: Results obtained in the pharmacognostic aliases expressed as mean \pm standard deviation.

The pharmacognostic analyzes aim to assess the quality and purity of certain plant drug when used as raw material for the development of phytotherapeutic and phytocosmetic products. In general, quality control parameters, according to the Pharmacopoeia Brazil (2010), include the absence of foreign elements in the drug; especially dirtiness of earthly origin (sand, stone and soil), insects and other organisms; the determination of moisture, non-compacted apparent density, determination of $\mathrm{pH}$ and the content of total ash. It is worth noting that this type of analysis is important, since the presence of impurities and poor quality of herbal drugs marketed in fair and official 
Citation: Gonçalves RC,Favorito Machado AP,Barbosa Fernandes IL,Batista de Oliveira H, Guilherme Malafaia (2016) Pharmacognostic Characterization, Bioactive Compounds and Powder Antioxidant Action of Leaves of Araca (Psidium cattleianum(Myrtaceae)). Gen Med (Los Angeles) 4: 276. doi:10.4172/2327-5146.1000276

Page 3 of 6

establishments suggest that they may have been tampered with or that there was poor maintenance and negligence in preparing the same.

According to Nascimento et al. [27], the high content of impurities in plant drugs can result in health problems to those who use the products based on medicinal plants (whether for food or medicinal purposes), because do not cause the expected therapeutic effect and even the occurrence of adverse reactions such as poisoning and allergic reactions, resulting in a serious health problem.

In this herein study, the drug powder had an apparent density, seen as low density according to Pharmacopoeia Brazil (2010) [20]. This parameter can directly influence the extraction process and obtainment of extracts with different solvents once the low density of plant drug can indicate difficulties in compression of the particles and therefore the necessity of using a larger volume of solvent in the process maceration to avoid the fluctuation of powdered drug [28].

Regarding to $\mathrm{pH}$, it was found solution of acid character, suggesting that the leaf of this plant should contain predominantly acids constituents. It is worth noting, as Hubinger [29], which in plants are various inorganic and organic acids present in general combined in the form of salts, esters, lactones, lipids, essential oils, resins, proteins, among others. For the author, one of these acids also lies in the free state, solubilized in the cytoplasm, which can characterize the basic character, neutral and acid of specific plant extract. In the case of herbal drugs, the acid nature of the chemicals contained in the plant material has great importance because, generally avoids the presence and attack of micro-organisms [30].

Another important point to be considered in identifying purity of herbal drugs relates to the determination of the content of total ash. The total ash, derived from plant tissue (physiological ash) and derived from foreign materials (non-physiological ash), allow verifying the presence of non-volatile inorganic impurities which may be present as contaminants in the plant material $[31,32]$ after incineration process (taken to coal state). No data recommended by Pharmacopoeia Brazil, 2010 [20] to assess the total ash content obtained for the studied spp., so the results of this study can serve as a benchmark for this plant drug.

Another essential parameter to ensure the quality of vegetable drug is the residual water content found in the dry plant material. The determination of moisture of the plant drug had a percent within the specified limit as regarding by the current Pharmacopoeia, which provide maximum moisture content between $8 \%$ and $14 \%$, depending on the species, and the part of the plant in question (Pharmacopoeia Brazil, 2010) [20].

It is important to note that the moisture content found in vegetable drugs, especially sprayed, is an important index because excess moisture or excessive drying reduces the pharmacological value of the drug by promoting the degradation of compounds assets [32]. Importantly, the excess water allows the action of enzymes that can degrade active chemical constituents present in the plant sample by hydrolysis reactions [31]. In addition, a high percentage of residual water exposes the plant drug to microbial growth, especially fungi [31] which may result in the loss of material. The moisture content in the leaves powder of the studied species, showed an amount considered safe and that ensures the stability of the material.

\section{Quantification of bioactive compounds}

The results of quantitation of phenolic compounds, flavonoids, tannins, vitamin $\mathrm{C}$ and $\beta$-carotene in $P$. cattleianum leaf powder (moisture range of $9.32 \pm 1.006 \%$ ) are shown in $\beta$-Carotene Table 2 .

\begin{tabular}{|l|l|l|l|}
\hline $\begin{array}{l}\text { Bioactive } \\
\text { compounds }\end{array}$ & $\begin{array}{l}\text { Results } \\
\text { (mg/100 g } \mathbf{g} \mathbf{\text { Standard }} \\
\text { Deviation) }\end{array}$ & Linear equation & $\begin{array}{l}\text { Correlation } \\
\text { coefficient } \mathbf{R}^{2} \\
\text { ) }\end{array}$ \\
\hline $\begin{array}{l}\text { Phenolic } \\
\text { compounds }\end{array}$ & $964.20 \pm 3.69$ & $\mathrm{Y}=0.016 \mathrm{x}+0.000$ & 0.999 \\
\hline Flavonoids & $631.50 \pm 17.72$ & - & - \\
\hline Tannins & $373.237 \pm 45.2$ & $\mathrm{Y}=0.001 \mathrm{x}+0.005$ & 0.991 \\
\hline Vitamin C & $446.30 \pm 3.40$ & - & - \\
\hline$\beta-$ Carotene & $19.19 \pm 0.75$ & - & - \\
\hline
\end{tabular}

Table 2: Results obtained in the quantification of bioactive compounds in Psidium cattleianum leaf powder.

The plant drug presents important bioactive compounds amount, justifying some therapeutic activities of popular use of this species. The leaves have high levels of bioactive compounds in comparison with the results of other studies conducted with fruits of species, of the botanical family Myrtaceae, as shown in Table 3.

\begin{tabular}{|c|c|c|c|c|c|}
\hline Bioactive compounds & Plant species & Feedstock & Methodology used & $\begin{array}{l}\text { Result } \\
\left(\mathrm{mg} 100 \mathrm{~g}^{-1}\right)\end{array}$ & Author (s) \\
\hline \multirow[t]{4}{*}{ Phenolic compounds } & $\begin{array}{l}\text { Uvaia } \\
\text { Eugenia pyriformis }\end{array}$ & Pulp in natura & $\begin{array}{l}\text { Folin and Ciocalteau } \\
{[21]}\end{array}$ & 127 & $\begin{array}{l}\text { Rufino et al. } \\
\text { [33] }\end{array}$ \\
\hline & $\begin{array}{l}\text { Jambolão } \\
\text { Syzygium jambolanum }\end{array}$ & Pulp in natura & $\begin{array}{l}\text { Folin and Ciocalteau } \\
\text { [21] }\end{array}$ & 185 & $\begin{array}{l}\text { Rufino et al. } \\
\text { [33] }\end{array}$ \\
\hline & $\begin{array}{l}\text { Goiaba } \\
\text { Psidium guajava }\end{array}$ & Frozen pulp & - & 83.0 & Kuskoski et al. [34] \\
\hline & $\begin{array}{l}\text { Acerola } \\
\text { Malpighia glabra }\end{array}$ & Frozen pulp & - & 580.1 & $\begin{array}{l}\text { Rufino et al. } \\
\text { [33] }\end{array}$ \\
\hline Flavonoids & Acerola & Pulp in natura & Lees and Francis & 9.31 a 20.22 & Lima et al. \\
\hline
\end{tabular}


Citation: Gonçalves RC,Favorito Machado AP,Barbosa Fernandes IL,Batista de Oliveira H, Guilherme Malafaia (2016) Pharmacognostic Characterization, Bioactive Compounds and Powder Antioxidant Action of Leaves of Araca (Psidium cattleianum(Myrtaceae)). Gen Med (Los Angeles) 4: 276. doi:10.4172/2327-5146.1000276

Page 4 of 6

\begin{tabular}{|c|c|c|c|c|c|}
\hline & Malpighia glabra & & [22] & & [35] \\
\hline & $\begin{array}{l}\text { Cagaita } \\
\text { Eugenia dysenterica }\end{array}$ & Pulp in natura & $\begin{array}{l}\text { Lees and Francis } \\
\text { [22] }\end{array}$ & 7.07 & $\begin{array}{l}\text { Santos } \\
{[36]}\end{array}$ \\
\hline & $\begin{array}{l}\text { Cagaita } \\
\text { Eugenia dysenterica }\end{array}$ & Frozen pulp & $\begin{array}{l}\text { Lees and Francis } \\
\text { [22] }\end{array}$ & 4.86 & $\begin{array}{l}\text { Santos } \\
{[36]}\end{array}$ \\
\hline & $\begin{array}{l}\text { Cagaita } \\
\text { Eugenia dysenterica }\end{array}$ & Atomized pulp & $\begin{array}{l}\text { Lees and Francis } \\
\text { [22] }\end{array}$ & 42.93 & $\begin{array}{l}\text { Santos } \\
{[36]}\end{array}$ \\
\hline \multirow[t]{3}{*}{ Tannins } & $\begin{array}{l}\text { Cagaita } \\
\text { Eugenia dysenterica }\end{array}$ & Pulp in natura & $\begin{array}{l}\text { Waterman and Mole } \\
\text { [23] }\end{array}$ & 16.62 & $\begin{array}{l}\text { Santos } \\
{[36]}\end{array}$ \\
\hline & $\begin{array}{l}\text { Cagaita } \\
\text { Eugenia dysenterica }\end{array}$ & Frozen pulp & $\begin{array}{l}\text { Waterman and Mole } \\
\text { [23] }\end{array}$ & 21.30 & $\begin{array}{l}\text { Santos } \\
{[36]}\end{array}$ \\
\hline & $\begin{array}{l}\text { Cagaita } \\
\text { Eugenia dysenterica }\end{array}$ & Atomized pulp & $\begin{array}{l}\text { Waterman and Mole } \\
{[23]}\end{array}$ & 67.00 & $\begin{array}{l}\text { Santos } \\
{[36]}\end{array}$ \\
\hline \multirow[t]{4}{*}{ Vitamin C } & $\begin{array}{l}\text { Cagaita } \\
\text { Eugenia dysenterica }\end{array}$ & Pulp in natura & - & 40.11 & $\begin{array}{l}\text { Oliveira et al. } \\
\text { [37] }\end{array}$ \\
\hline & $\begin{array}{l}\text { Cagaita } \\
\text { Eugenia dysenterica }\end{array}$ & Pulp in natura & HPLC-DAD & 34.11 & $\begin{array}{l}\text { Cardoso et al. } \\
\text { [38] }\end{array}$ \\
\hline & $\begin{array}{l}\text { Cagaita } \\
\text { Eugenia dysenterica }\end{array}$ & Pulp in natura & $\begin{array}{l}\text { Benassi and Antunes } \\
\text { [41] }\end{array}$ & 27.46 & $\begin{array}{l}\text { Silva and Santos Júnior } \\
\text { e Ferreira } \\
\text { [37] }\end{array}$ \\
\hline & $\begin{array}{l}\text { Cagaita } \\
\text { Eugenia dysenterica }\end{array}$ & Frozen pulp & $\begin{array}{l}\text { Benassi and Antunes } \\
\text { [41] }\end{array}$ & 26.97 & $\begin{array}{l}\text { Silva and Santos Júnior } \\
\text { e Ferreira } \\
\text { [39] }\end{array}$ \\
\hline \multirow[t]{2}{*}{$\beta$-Carotene } & $\begin{array}{l}\text { Cagaita } \\
\text { Eugenia dysenterica }\end{array}$ & Pulp in natura & HPLC-DAD & 0.77 & $\begin{array}{l}\text { Cardoso et al. } \\
\text { [38] }\end{array}$ \\
\hline & $\begin{array}{l}\text { Goiaba } \\
\text { Psidium guajava }\end{array}$ & Fresh fruit & HPLC-DAD & 13.8 & Charoensiri et al. [40] \\
\hline
\end{tabular}

Table 3: The results obtained for bioactive compounds in fruit species, of the botanical family Myrtaceae.

Studies have shown that phenolic compounds contribute to the flavor and color of many plants, and many of them possess antioxidant, anti-inflammatory, antiviral, anti-allergic, antispasmodic, antibacterial, cardioprotective and vasodilatory activity [41-43]. Referring to the flavonoids, various functions are assigned to plants as protection against the incidence of ultraviolet rays, insect, fungi, viruses and bacteria attack; attraction of animals with the purpose of pollination and control of action of plant hormones [44]. Regarding to therapeutic application, the flavonoids, have been recognized for having, antiinflammatory, anti-cancer, anti-spasmodic, anti-ulcer, antiviral properties and inhibitor of the enzyme acetylcholinesterase [45-50].

The tannins act as natural food repellents to a variety of herbivores which prevent part of the plant, such as green fruit or the plant completely. The tannins also act in defense to microorganisms' attack. The heartwood of many trees contains high concentrations of tannins, which help to prevent decomposition by fungi and bacteria [51]. Among the pharmacological effects of tannins can be mentioned antiseptic, antimicrobial, antitumor, antiviral action; molluscicide (snail pellets), wound, burns and inflammation healing, inhibition of bacterial enzymes and antidiarrheal effect [52-54].
The vitamin $\mathrm{C}$ is used in the prevention of numerous diseases, such as diabetes, cataracts, glaucoma, macular degeneration, atherosclerosis, stroke, heart disease and cancer, in addition to stimulating the immune system and has antioxidant [55]. Similarly, carotenoids are associated with many therapeutic properties such as antioxidant, epithelial protection and fetal development [55].

\section{Determination of antioxidant activity}

The linear equation obtained $(y=0.009 x+0.015)$ with a coefficient of determination $\left(\mathrm{R}^{2}\right)$ equal to 0.997 was used to determine the effective concentration $\left(\mathrm{EC}_{50}\right)$, in other words the amount of plant drug required to reduce the initial concentration of DPPH by $50 \%$. The data show that the plant drug powder drug has scavenging activity of free radicals with a value of $\mathrm{EC}_{50}=97.91 \pm 0.49 \mu \mathrm{mol} \mathrm{g}{ }^{-1}$. This means that 1 gram of plant drug powder has antioxidants capable of reducing $97.91 \mu \mathrm{mol}$ of DPPH by $50 \%$.

The Table 4 shows the results of the percentage of free radical DPPH capture by antioxidants present in the $P$. cattleianum leaf according to the concentrations tested. 


\begin{tabular}{|l|l|}
\hline $\begin{array}{l}\text { Concentration of solution } \mathbf{( m g} \\
\text { L-1) }\end{array}$ & $\begin{array}{l}\text { Percentage of free radical DPPH } \\
\text { capture }\end{array}$ \\
\hline 5000 & $38 \%$ \\
\hline 7000 & $43 \%$ \\
\hline 10000 & $55 \%$ \\
\hline 10000 & $83 \%$ \\
\hline
\end{tabular}

11. Santos MS, Petkowicz CLO, Wasiacki G, Nogueira A, Carneiro EBB (2007) Characterization of red araca juice. (Psidium cattleianum Sabine) extracted mechanically and treated enzymatically. Acta Scientiarum Agronomy 29: 617-621.

12. Patel S (2012) Cattleianum: a review on prospects and threats. Rev Environ Sci Biotecnol 11: 243-248.

13. Moresco HH, Pizzolatti MG, Brighente IMC (2012) Constituents of Psidium cattleyanum. Chem Nat Compd 47: 1028.

14. Medina AL, Hass LI, Chaves FC, Salvador M, Zambiazi RC, et al. (2011) Araçá (Psidium cattleianum Sabine) fruit extracts with antioxidante and antimicrobial activies and antiproliferative effect on human câncer cells. Food Chemistry 128: 916-922.

Table 4: Percentage of free radical DPPH capture.

The results show that the plant drug powder, shows good antioxidant activity. The antioxidant activity has been described for some species, of the Myrtaceae family, as Psidium guajava [56], Eugenia uniflora [57] Myrciaria cauliflora [58]. Some authors, such as Fetter et al. [59], Medina [14] Nora et al. [60] reported antioxidant action in fruit of Araçás spp.,. However, there are still no reports of antioxidant potential studies with the leaf of this species.

\section{Conclusions}

The pharmacognostic point of view, the results found for the plant drug under study are in line with the requirements recommended by the Pharmacopoeia Brazil, 2010. Therefore, the conditions used in the different steps of obtaining plant drug (from the collection of leaves to the final product) contributed to the quality of raw material used in the study. The results showed that the plant drug has significant quantities of bioactive compounds as well as antioxidant activity. It is noteworthy that these findings open up prospects for the realization of other biological assays for evidence of possible biological activities presented by the plant species.

\section{References}

1. Viegas C, Bolzani VDAS, Barreiro EJ (2006) Natural products and modern medicinal chemistry. New Chemistry 29: 326-337.

2. Silva NCC, Fernandes A (2010) Biological properties of medicinal plants: a review of their antimicrobial activity. J Venom Anim Toxins incl Trop Dis 16: 402-413.

3. Leite AC, Placeres Neto A, Ambrozin ARP, Fernandes JB, Vieira PC, et al. (2010) Trypanocidal activity of flavonoids and limonoids isolated from Myrsinaceae and Meliaceae active plant extracts. Braz J Pharmacog 20: 01-06.

4. Souza TM, Santos LE, Moreira, RRD, Rangel VLBI (2005) Evaluation of the photoprotective activity of Achillea millefolium L. (Asteraceae). Braz J Pharmacog 15: 36-38.

5. Suárez A, Ulate G, Ciccio JF (2000) Hypotensive action of an aqueous extract of Pimenta dioica (Myrtaceae) in rats. Rev Biol Trop 48: 53-58.

6. Fernández A, Álvares A, García D, Sáenz T (2001) Anti-inflammatory effect of Pimenta racemosa var. ozua and isolation of the triterpene lupeol. Farmaco 56: 335-338.

7. García MD, Fernández MA, Alvarez A, Saenz MT (2004) Antinoceptive and anti-inflammatory effect of aqueous extract from leaves of Pimenta recemosa var. ozua (Mirtaceae). J Ethnopharmacol 91: 69-73.

8. Tassara H (1996) Fruits in Brazil. São Paulo: Company of the Arts. pp: $10-12$.

9. Haminiuk CWI, Sierakowski MR, Vidal JRMB, Masson ML (2006) Influence of temperature on the rheological behavior of whole aracá pulp (Psidium cattleianumsabine). LWT-Food Sci Technol 39: 426-430.

10. Lorenzi H (2006) Brazilian and exotic fruits cultivated: (of consumption in natura). São Paulo: Plantarum Institute of Flora Studies. p: 236.

15. Neri-Numa IA, Carvalho Silva LB, Morales JP, Malta LG, Muramoto MT, et al. (2013) Evaluation of the antioxidant, antiproliferative and antimutagenic potential of araçá-boi fruit (Eugenia stipitata Mc Vaugh Myrtaceae) of the Brazilian Amazon Forest. Food Res Int 50: 70-76.

16. Faleiro JH, Gonçalves RC, Santos MNGS, Silva DP, Naves PLF, et al. (2016) The chemical featuring, toxicity, and antimicrobial activity of Psidium cattleianum (Myrtaceae) Leaves. New Journal of Science 2016: 1-8.

17. Fauth S, Campos AR, Silveira ER, Rao VS (2002) Effects of plant essential oils on ketamine-induced sleep time in mice. Rev Bras Farmacogn 12: 112-113.

18. Huang D, OU B, Prior R (2005) The chemistry behind antioxidant capacity assays. J Agric Food Chem 53: 841-856.

19. Atoui AK, Mansouri A, Boskou G, Kefalas P (2005) Tea and herbal infusions: Their antioxidant activity and phenolic profile. Food Chem 89: 27-36.

20. Brasil (2010) Brazilian Pharmacopoeia. National Health Surveillance Agency.

21. Roesle RR, Malta LG, Carrasco LC, Holanda RB, Sousa CAAS, et al. (2007) Antioxidant activity of cerrado fruits. Food Sci Technol Campinas 27: 53-60.

22. Lees DH, Francis FJ (1972) Standardization of pigment analyses in cranberries. Hort Science Alexandria 7: 83-84.

23. Waterman PG, Mole S (1994) Analysis of phenolic plant metabolites. Blackwell Scientific Publications, London.

24. Rodriguez-Amaya DB (1999) A guide to carotenoid analysis in foods. ILSI Human Nutrition Institute. ILSI Press, Estados Unidos. p: 64.

25. Terada M, Watanabe Y, Kunitoma M, Hayashi E (1979) Differential rapid analys ascorbic acid and ascorbic acid 2-sulfate by dinitrophenilhydrazine method. Annals of Biochemistry 4: 604-608.

26. Sánchez-Moreno C, Larrauri JA, Saura-Calixto F (1998) A procedure to measure the antiradical efficiency of polyphenols. J Sci Food Agr 76: 270276.

27. Nascimento V, Lacerda E, Melo J, Lima C, Amorim E, et al. (2005) Quality control of medicinal products marketed in the city of Recife - PE: fennel (Pimpinella anisum L.), stone breakworm (Phyllanthus spp.), Holy spinach (Maytenus ilicifolia Mart.) and chamomile (Matricaria recutita L). Rev Bras Pl Med 7: 56-64.

28. Amarante CB (2010) Chemical, pharmacognostic, biological and pharmacological activity of Montrichardia linifera (Arruda) Schott. Belém. Ph.D Thesis, Federal University of Pará, Belém. p: 320.

29. Hubinger ZS (2009) Pharmacognostic study and development of antioxidant action phytocosmetics of the fruits of Dimorphandra mollis Benth, (Leguminosae-caesalpinioideae) Araraquara 148f. Paulista State University.

30. Longhini R, Raksa SM, Oliveira ACP, Svidzinski TIE, Franco SL (2007) Obtaining extracts of propolis under different conditions and evaluating their antifungal activity. Rev arms Farmacogn 17: 388-395.

31. Farias MR (2001) Evaluation of the quality of plant raw materials. In: Simões CMO, Schenkel EP, Gosmann G, Mello JCP, Mentz LA, et al. (eds.) Pharmacognosy: from plant to drug (5th edn.) Porto Alegre: Universidade UFRGS. 
Citation: Gonçalves RC,Favorito Machado AP,Barbosa Fernandes IL,Batista de Oliveira H, Guilherme Malafaia (2016) Pharmacognostic Characterization, Bioactive Compounds and Powder Antioxidant Action of Leaves of Araca (Psidium cattleianum(Myrtaceae)). Gen Med (Los Angeles) 4: 276. doi:10.4172/2327-5146.1000276

Page 6 of 6

32. Silva Júnior JOC (2006) Preparation and evaluation of semi-solid phytotherapeutic pharmaceutical form containing dry extract by nebulization of Simphytum officinale L. (confrei). PhD thesis, University of São Paulo.

33. Rufino MSM, Alves RE, Brito ES, Pérez-Jiménez J, Saura-Calixto F, et al. (2010) Bioactive compounds and antioxidant capacities of 18 nontraditional tropical fruits from Brazil. Food Chemistry 121: 996-1002.

34. Kuskoski EM, Asuero AG, Troncoso AM, Mancini-Filho J, Fett R (2005) Application of various chemical methods to determine antioxidant activity in fruit pulp. Food Sci Technol, Campinas 25: 726-732.

35. Lima AR, Barbosa VC, Santos Filho PR, Gouvêa CMCP (2006) In vitro evaluation of the antioxidant activity of the hydroalcoholic extract of burdock leaves. Braz J Pharmacog 16: 531-536.

36. Santos MNG Evaluation of pulp of cagaita (Eugenia dysenterica DC). Master's Dissertation, Federal University of Goiás, Goiânia, Go.

37. Oliveira MES, Pantoja L, Duarte WF, Collela CF, Valarelli LT, et al. (2011) Fruit wine produced from cagaita (Eugenia dysenterica 78 DC) by both free and immobilised yeast cell fermentation. Food Res Int 44: 2391-2400.

38. Cardoso LM, Martino HSD, Moreira AVB, Ribeiro SMR, PinheiroSant'ana HM (2011) Cagaita (Eugenia dysenterica DC.) of the Cerrado of Minas Gerais, Brazil: Physical and chemical characterization, carotenoids and vitamins. Food Res Int 44: 2151-2154.

39. Silva MR, Santos RTOS, Ferreira CCC (2008) Stability of vitamin C in fresh cajita and during storage of pulp and soda. Pesq Agropec Trop 38: 53-58.

40. Charoensiri R, Kongkachuichai R, Suknicom S, Sungpuag P (2009) Beta carotene, lycopene, and alpha-tocopherol contents of selected Thai fruits. Food Chem 113: 202-207.

41. Benassi MT, Antunes AJ (1988) A comparison of metaphosphoric and oxalic acids as extractants solutions for the determination of vitamin $\mathrm{C}$ in selected vegetables. Braz Arch Biol Technol 31: 507-513.

42. Carvalho JCT, Gosmann G, Schenkel EP (2004) Simple and heterosidic phenolic compounds. In: Simões CMO, Schenkel EP, Gosmann G, Mello JCP, Mentz LA, et al. (eds.). Pharmacognosy: from the plant to the medicine (5th edn.). Rev Ampl Florianópolis. pp: 519-535.

43. Balasundram N, Sundram K, Samman S (2006) Phenolic compounds in plants and agri-industrial by-products: antioxidant activity, occurrence, and potencial uses. Food Chem 99: 191-203.

44. Harborne JB, Williams CA (2000) Advances in flavonoid research since 1992. Phytochemistry 55: 481-504.

45. Wollenweber E, Wehde R, Dörr M, Lang G, Stevens JF (2000) C-Methylflavonoids from the leaf waxes of some Myrtaceae. Phytochemistry 55: 965-970.

46. Amaral ACF, Kuster RM, Bessa WS, Barnes RA, Kaplan MAC, et al. (2001) Flavonoids and other phenolics from leaves of two Marlierea spp., (Myrtaceae). Biochem Syst Ecol 29: 653-654.
47. Amaral FMM, Ribeiro MNS, Barbosa-Filho JM, Reis AS, Nascimento FRF, et al. (2006) Plants and chemical constituents with giardicidal activity. Rev Bras Farmacogn 16: 696-720.

48. Barbosa-Filho JM, Medeiros KCP, Diniz MFFM, Batista LM, AthaydeFilho PF, et al. (2006) Natural products inhibitors of the enzyme acetylcholinesterase. Braz J Pharmacog 16: 258-285.

49. Benavente-Garcia O, Castillo J (2008) Update on uses and properties of citrus flavonoids: New findings i anticancer, cardivascular, and antiinflammatory activity. J Agric Food Chem 56: 6185-6205.

50. Momesso LS, Moura RMX, Constantino DHJ (2009) Antitumor activity of Ageratum conyzoides L. (Asteraceae). Rev Bras Farmacognos 19: 660-663.

51. Yamada T (2004) Resistance of plants to pests and diseases: can it be affected by crop management? Agricultural Information Potafos No 108.

52. Santos SC, Mello JCP (2004) Taninos. In: Simões CMO, Schenkel EP, Gosmann G, Mello JCP, Mentz LA, et al. (eds.) Farmacognosia: da planta ao medicamento (5th edn.). Porto Alegre: UFRGS. pp: 615-656.

53. Monteiro JM, Albuquerque UP, Amorim ELC (2005) Tannins: an approach from chemistry to ecology. New Chem 28: 892-896.

54. Souza TM, Moreira RRD, Pietro RCLR, Isaac VLB (2007) Evaluation of the antiseptic activity of dry extract of Stryphnodendron adstringens (Mart.) Coville and of cosmetic preparation containing this extract. Rev bras farmacogn 17: 71-75.

55. Iqbal K, Khan A, Khattak MM (2004) Biological significance of ascorbic acid (vitamin C) in human health - a review. Pak J Nutr 3: 5-13.

56. Nascimento RJ, Araújo CR, Melo EA (2010) Antioxidant activity of extracts of guava agroindustrial residue (Psidium guajava). Alim Nutr 21: 209-216.

57. Moreno LD, Bertanha BJ, Jorge N (2010) Pitanga (Eugenia uniflora L.) seeds: antioxidant potential and fatty acid profile / Pitanga (Eugenia uniflora L.). Rev Inst Adolfo Lutz 69: 175-180.

58. Catunda-Jr, FEA, Luciano JHS, Morais SM (2002) Antioxidant activity of essential oils from plants in Northeast Brazil. Science and Technology Journal 4: 23-29.

59. Fetter MR, Vizzotto M, Corbelin DD, Gonzalez TN (2010) Functional properties of araçá-amarelo, araçá-vermelho (Psidium cattleyanum Sabine) and araçá-pera (P. acutangulum D.C.) grown in Pelotas / RS. Braz. J Food Technol.

60. Nora CD, Jablonski A, Rios AO, Hertz PF, Jong EV, et al. (2014) The characterisation and profile of the bioactive compounds in red guava (Psidium cattleyanum Sabine) and guabiju (Myrcianthes pungens (O. Berg) D. Legrand). Int J Food Sci Tech 49: 1842-1849. 